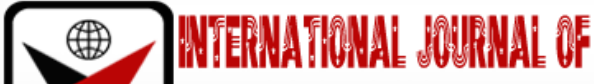

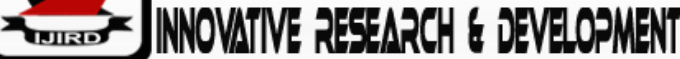

ISSN 2278 - 0211 (Online)

\section{Media and Source Markets for Domestic Tourism in Tanzania: Study of Kitulo National Park}

\author{
Kezia Herman Martin Mkwizu \\ Ph.D. Student, The Open University of Tanzania, Tanzania
}

\begin{abstract}
:
This paper aims to analyze the media and source markets for domestic tourism in Tanzania. The specific objectives are to assess the media used by domestic tourists to source information about Kitulo National Park, and establish the source markets for Kitulo National Park. The research area of this study is Kitulo National Park located in Southern Tanzania. A descriptive design approach was used in this study. Semi structured questionnaires were deployed to obtain quantitative data from a sample size of 105 domestic tourists and subjected to descriptive analysis. Findings indicated that television is the major media used by domestic tourists to source information about Kitulo National Park. On the other hand, the major source markets for Kitulo National Park are Njombe and Mbeya. Future research can explore tourist information and source markets for domestic tourism.
\end{abstract}

Kevwords: Media, source markets, domestic tourism, national park, Tanzania

\section{Introduction}

Tourism as one of the economic pillars around the world recorded over 1.2 billion international tourist arrivals in 2016 (UNWTO, 2017). Although much is known about international tourism, there is limited literature about media and source markets for domestic tourism. Ngoka (2013) stated that in Nigeria between 2002-2006 there were 103, 552 domestic tourists who visited Yankari National Park compared to only 11,936 international tourists. In 2012 there were 372, 409 domestic tourists that contributed to $40.5 \%$ of the total tourists who visited national parks in Tanzania (Mkwizu, 2016b). Various studies have concentrated on media and source markets for international tourism rather than domestic tourism (Mungai, 2011; Muratha, 2013; Kronenberg et al., 2015). In Tanzania there are several studies in tourism (Lwoga, 2011; Philemon, 2011; Nguni, 2014; Kazuzuru, 2014; Lwoga et al., 2015; Safari et al., 2015; Mwasha et al., 2016). For instance, Kazuzuru (2014) was interested on the history of tourism industry from the perspective of international tourism. However, these studies did not focus on media and source markets for domestic tourism. Few studies have mentioned media in relation to promotion of domestic tourism (Anderson, 2010; Mariki et al., 2011), but these studies do not avail updated research on Tanzania. Furthermore Anderson (2010) mentioned that tourism organizations focused on international markets as opposed to domestic markets in Tanzania. Mkwizu (2015) also mentioned that limited literature is a study challenge in research. Hence this paper contributes knowledge on domestic tourism by analyzing media and source markets. The specific objectives of this paper are to assess media, and establish source markets for Kitulo National Park in Southern Tanzania.

\section{Significance of the Study}

This paper provides updated research on media and source markets for domestic tourism which can be used by Tanzania National Parks (TANAPA), Tanzania Tourist Board (TTB) and other tourism organizations such as Tanzania Association of Tour Operators (TATO) to improve promotion and marketing efforts for Kitulo National Park in Tanzania. Researchers can also use the information as knowledge base to understand promotion and marketing of national parks for domestic tourism.

\section{Literature Review}

\subsection{Conceptual Definitions}

\section{$\underline{\text { 3.1.1. Media }}$}


In Tanzania, the government through the Ministry of Natural Resources and Tourism (MNRT), and its agencies TTB and TANAPA promote domestic tourism using various media. Mungai (2011) mentioned promotion in tourism using advertising tools such as newspapers, television, magazines or radio. MNRT, TTB and TANAPA use exhibitions, radio, magazines, television and social media to promote national parks (TTB, 2014; TANAPA, 2015). Spencer (2013) indicated TV is widely used for advertising attractions. Tehrani et al (2014) stated that TV advertising is regarded as expensive but it is not because it provides geographical coverage, audience access and advertisement of attractions. In addition, Ghosh (2016) referred to social media as a new media. For purposes of this paper, the assessed media are radio, social media and television.

\subsubsection{Source Markets}

Several reports and studies show source markets for international tourism in Tanzania (Bank of Tanzania, 2009; MNRT, 2011; MNRT, 2012; Kazuzuru, 2014, Bank of Tanzania \& National Bureau of Statistics, 2016). For instance, MNRT (2012) showed major source markets for international tourism in Tanzania were Africa (488,745), Europe (330,207), Americas $(103,064)$, East Asia and Pacific $(77,097)$, South Asia $(56,597)$ and Middle East $(21,348)$. However, there is lack of data for domestic tourism markets hence very difficult to know which source markets to target for promotion improvements. In this study, source markets are those markets which contribute domestic tourists to Kitulo National Park.

\subsection{Empirical Literature Review}

Globally studies such as Kronenberg et al (2015) investigated advertising expenditure shares for destination Sweden but focused on international tourists. Anurekha (2015) analyzed TV advertising directed to youth adults. Equally Kimbowa et al (2011) were interested to explore environmental implications of tourism development on River Nile in Uganda. Burugu et al (2013) were interested in hotel website linkage for destination Kenya. Macha et al (2014) did study domestic tourism and the focus was on promotion. Kazuzuru (2014) explored history, performance and challenges of tourism industry in Tanzania with the main focus on international tourism. These studies (Kimbowa et al., 2011; Mungai, 2011; Burugu et al., 2013; Macha et al., 2014; Kazuzuru, 2014) have not provided information on media and source markets for domestic tourism. Mariki et al (2011) was interested in wildlife-based tourism in northern protected areas of Tanzania and found that only 15\% used both TV and Radio as a source of information to know about national parks. Recent studies focused on content and uniqueness of message variables to study TV advertising in Tanzania (Mkwizu, 2016a; Mkwizu, 2016c). Equally these studies (Mkwizu \& Matama, 2017a; Mkwizu, 2017c; Mkwizu, 2017d; Sing'ambi \& Lwoga, 2017) have done research on domestic tourism in Tanzania but the focus was not on source markets. For example, Mkwizu and Matama (2017a) examined frugal generation in relation to domestic tourism. This paper analyzed media and source markets for Kitulo National Park in Southern Tanzania.

\section{Methodology}

Tanzania has 16 national parks which are Arusha, Gombe, Katavi, Kilimanjaro, Kitulo, Mahale, Manyara, Mikumi, Mkomazi, Ruaha, Rubondo, Saadani, Saanane, Serengeti, Tarangire and Udzungwa (Owusu, 2013; TANAPA, 2015; Figure 1). Tanzania national parks have tourism potential (Kijazi, 2012). This study selected Kitulo National Park due to the uniqueness of the high plateau with the largest spread of endemic wildflowers as shown on Figure 2.

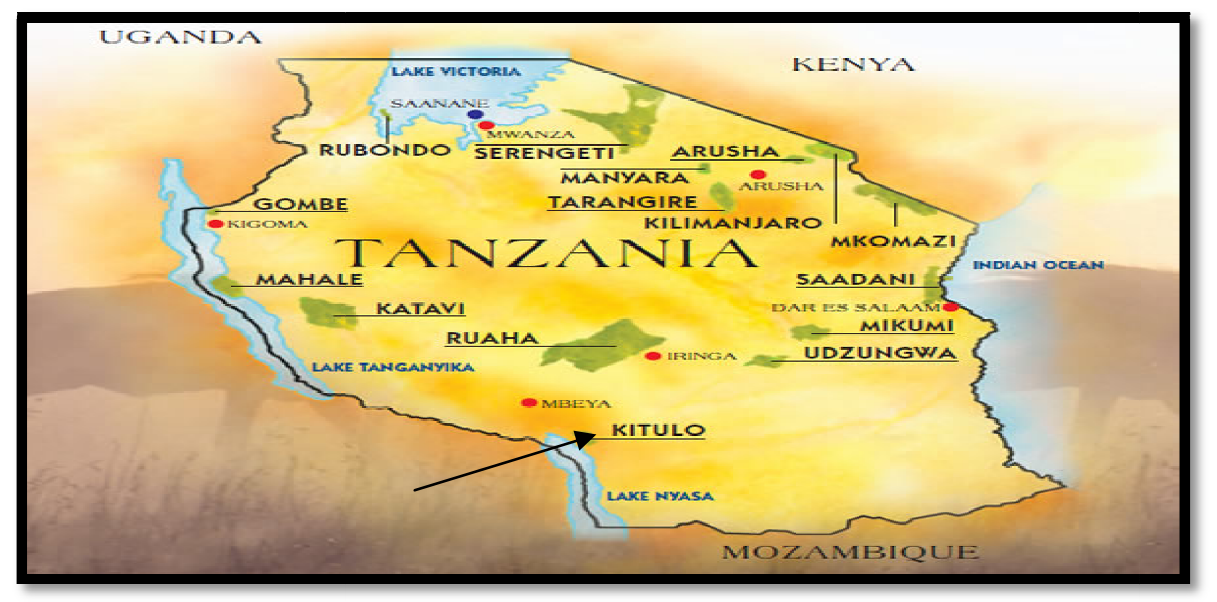

Figure 1: Map Showing Location of Kitulo National Park in Tanzania Source: TANAPA (2015) 


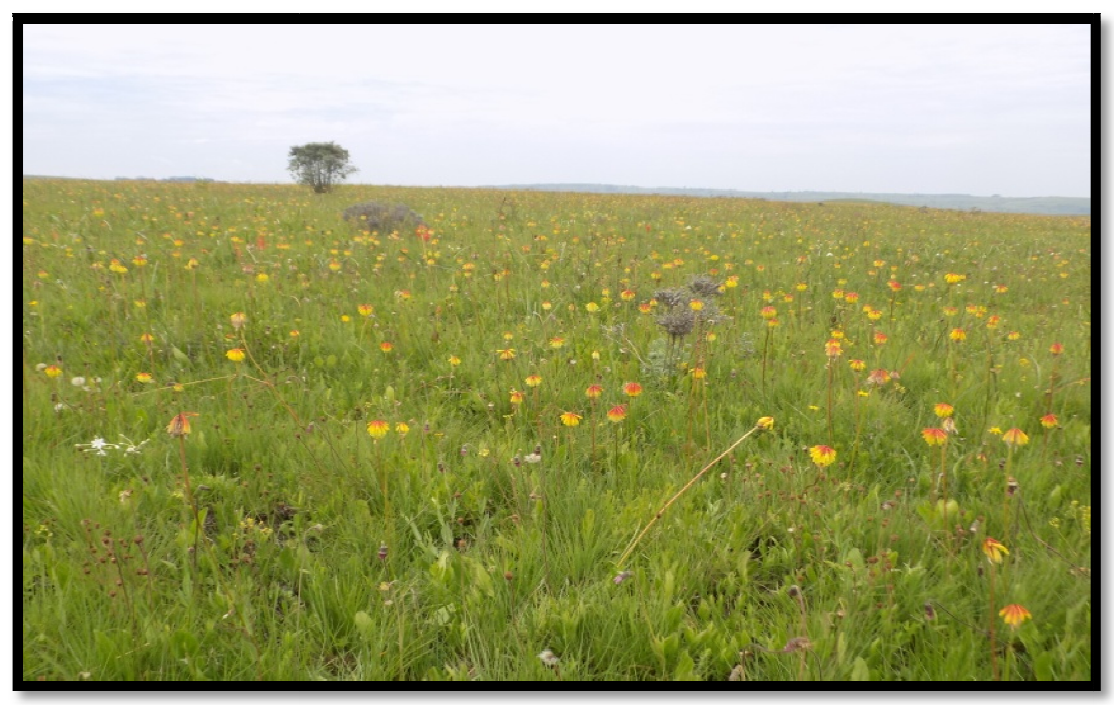

Figure 2: Wildflowers in Kitulo National Park in Tanzania Source: Mkwizu (2017b)

This paper deployed a cross-sectional descriptive research approach. The unit of analysis for this study is domestic tourists who visited Kitulo National Park. The reason for selecting Kitulo National Park is because of its tourism potential. This study adopted and customized media items from Ling et al (2010) and Mungai (2011) to measure how domestic tourists source information about Kitulo National Park. The source markets were measured using residence of domestic tourists who visited Kitulo National Park. This study is limited only to domestic tourists who visited Kitulo National Park and not potential visitors. Semi-structured questionnaires were administered to a sample size of 105 domestic tourists who visited Kitulo National Park in January 2015. There were 5 questionnaires which were not properly filled and therefore could not be used for analysis. There were 100 fully completed questionnaires subjected to descriptive statistical analysis. SPSS version 20 assisted the quantitative analysis. Descriptive analysis described the media used by domestic tourists and also the source markets for Kitulo National Park.

\section{Findings}

The profile of respondents for this study revealed that majority (51\%) were males, aged below 18 years old (73\%), with no income (91\%), and had secondary level of education (96\%). This implies that majority of domestic tourists who visited Kitulo National Park are characterized as the youth with secondary education.

Descriptive analysis results for media are shown on Table 1 which indicates majority (41\%) of domestic tourist who visited Kitulo National Park use TV to source information about Kitulo National Park.

\begin{tabular}{|c|c|c|}
\hline Variable & Frequencies (n) & Percentage (\%) \\
\hline Radio: Not Radio & 86 & $86 \%$ \\
Radio & $\underline{14}$ & $\underline{14 \%}$ \\
Total & 100 & 100 \\
\hline Social Media: Not Social Media & 98 & $98 \%$ \\
Social Media & $\underline{2} \%$ \\
Total & 100 & $100 \%$ \\
\hline Television: Not Television & 59 & $59 \%$ \\
Television & $\underline{41}$ & $100 \%$ \\
Total & 100 & \\
\hline
\end{tabular}

Table 1: Media by Domestic Tourists Who Visited Kitulo National Park Source: Field Data (2018)

Further descriptive analysis in Table 2 shows that the major source markets for Kitulo National Park are Njombe (74\%) and Mbeya (20\%). This suggests that most of the domestic tourists who visited Kitulo National Park are from Njombe. 


\begin{tabular}{|c|c|c|}
\hline Variable & Frequencies (n) & Percentage (\%) \\
\hline Dar es Salaam & 1 & 1 \\
\hline Morogoro & 1 & 1 \\
\hline Iringa & 3 & 3 \\
\hline Mbeya & 20 & 20 \\
\hline Arusha & 1 & 1 \\
\hline Njombe & 74 & 74 \\
\hline Table 2: Source Markets for Kitulo National Park in Tanzania \\
\multicolumn{2}{r}{ Source: Field Data (2018) }
\end{tabular}

\section{Conclusion}

This study aimed at analyzing media and source markets for domestic tourism. The first specific objective was to assess the media used by domestic tourists to source information about Kitulo National Park. The second objective was to establish source markets for Kitulo National Park. The domestic tourists who visited Kitulo National Park revealed that the majority use TV as a source of information to know about Kitulo National Park. The findings of this study differ from results of Mariki et al (2011). This implies that domestic tourists who visited Kitulo National Park prefer TV compared to social media and radio. The preference of TV by domestic tourists is due to TV programs showing national parks. The major source markets for Kitulo National Park are domestic tourists from Njombe and Mbeya while there were very few from Arusha, Dar es Salaam, Morogoro and Iringa. This implies that MNRT, TANAPA, TTB and tourism organizations such as TATO need to improve promotion of Kitulo National Park in order to increase the source markets and boost domestic tourism. This may be done through TV since it is the major source of information by domestic tourists. Future research can explore tourist information and source markets for domestic tourism.

\section{References}

i. Anderson, W. (2010). Marketing of Domestic Tourism in Tanzania. Dar es Salaam: Dar es Salaam University Press. ISBN 978-9976-60-454-8

ii. Anurekha, S. (2015). An analysis of television commercials directed to young adults- ELM and Social identification perspective. Journal of Humanities and Social Sciences, 20(7), 71-81.

iii. Bank of Tanzania. (2009). The 2009 International Visitors' Exit Survey Report. Retrieved from http://www.bottz.org/Publications/TTS/TTSS-2009.pdf

iv. Bank of Tanzania., \& National Bureau of Statistics. (2016). The 2016 International Visitors' Exit Survey Report. Retrieved from http://www.The2016_International_Visitors'_Exit_Survey_Report.pdf

v. Burugu, R., Nthiga, R., \& Bor, T. (2013). Proceedings of the $8^{\text {th }}$ ATLAS Africa Conference on African Tourism in Global Society: Central of Peripheral? : Advancing hotel website linkage as a potential technological tool for unlocking destination attraction in Kenya. Kigali, Rwanda.

vi. Ghosh, S. (2016). Change in marketing strategies due to new media. The International Journal of Business \& Management, 4(5), 376-386.

vii. Kazuzuru, B. (2014). History, performance and challenges of tourism industry in Tanzania. International Journal of Business and Social Sciences, 5(11), 120-131.

viii. Kimbowa, F., Nyakaana, J.B., \& Ahebwa, W.M. (2011). Environmental implications of tourism development on River Nile, Uganda. The Journal of the College of Humanities and Social Sciences Makerere University, 11(2), 6980.

ix. Kijazi, A.J.H. (2012). Proceedings of First-Pan African Conference on Sustainable Tourism in African National Parks'12: National overview of protected areas in Tanzania and their tourism potentials. Arusha, Tanzania.

x. $\quad$ Kronenberg, K., Fuchs, M., Salman, K., Lexhagen, M., \& Hopken, W. (2015). Economics effects of advertising expenditures-a Swedish destination study of international tourists. Scandinavian Journal of Hospitality and Tourism. Retrieved from http://dx.doi.org/10.1080/15022250.2015.1101013

xi. $\quad$ Ling, K.C., Piew, T.H., \& Chai, L.T. (2010). Determinants of consumer's attitude towards advertising. Canadian Social Sciences, 6(4), 114-126.

xii. Lwoga, N.B. (2011). Tourism: Meaning, Practices and History. Dar es Salaam: Dar es Salaam University Press. ISBN 978-9976-60-539-9

xiii. $\quad$ Lwoga, N.B., Anderson, W., Mapunda, B.B.B., Andersson, T.D., \& Mossberg, L. (2015). Proceedings of the $9^{\text {th }}$ ATLAS Africa Conference on Tourism and Inclusive Growth in Developing Economies'15: Scio-Psychological 
motives for stakeholder's engagement in conservation of built heritage attractions in Tanzania. Dar es Salaam, Tanzania.

xiv. Macha, L.J., Victor, M., \& Waane, S. (2014). Proceedings of International Conference on Sustainable Tourism in Developing Countries'14: Domestic tourism as a tool for promoting sustainable national tourism in developing countries. Dar es Salaam, Tanzania.

xv. $\quad$ Mariki, S.B., Hassan, S.N., Maganga, S.L.S., Modest, R.B \& Salehe F.S. (2011). Wildlife-based domestic tourism in Tanzania: Experiences from the northern tourist circuit. Retrieved from

http://www.ajol.info/index.php/ejesm/article/view/73349/62278

xvi. Ministry of Natural Resources and Tourism. (2011). Tourism Division: The 2011 Tourism Statistics Bulletin. Dar es Salaam.

xvii. Ministry of Natural Resources and Tourism. (2012). Tourism Division: The 2012 Tourism Statistics Bulletin. Dar es Salaam.

xviii. Mkwizu, K.H. (2015). Proceedings of the 11th International Operations Research Society of Eastern Africa Conference'15: PhD milestone and Study Challenges. Dar es Salaam, Tanzania.

xix. $\quad$ Mkwizu, K.H.M. (2016a). Domestic Tourists' Attitude towards Television Advertising in Tanzania. The International Journal of Business \& Management, 4(6), 364-370. Retrieved from http://www.theijbm.com/2016-2/june-16

xx. Mkwizu, K.H.M. (2016b). Proceedings of the 25th Annual ATLAS Conference '16: Role of Domestic Tourism: An Evolutionary Economic Geography Approach in Tanzania. Canterbury, UK. Retrieved from http://www.atlaseuro.org/LinkClick.aspx?fileticket=q6iiKmLMg8Q\%3d\&tabid=248\&language=en-US

xxi. Mkwizu, K.H. (2016c). Intra-Destination Television Advertising on Domestic Tourism in Tanzania. The International Journal of Business \& Management, 4(7), 424-430. Retrieved from http://www.theijbm.com/2016-2/july-16

xxii. Mkwizu, K.H.M., \& Matama, R. (2017a). Frugal generation: Millennials Perspective of Domestic Tourists in Tanzania. The International Journal of Business \& Management, 5(7), 142-145.

xxiii. Mkwizu, K.H.M. (2017b). Promotion of National Parks for Domestic Tourism in Tanzania. The International Journal of Business \& Management, 5(7), 146-150.

xxiv. Mkwizu, K.H.M. (2017c). Proceedings of the 10 $10^{\text {th }}$ ATLAS Africa Conference on Africa's Tourism and Travel Competitiveness: Opportunities and Challenges'17: Influence of Media and Income on Domestic Tourists visiting Udzungwa National Park in Tanzania. Eldoret, Kenya. Retrieved from http://www.atlaseuro.org/LinkClick.aspx?fileticket=B431-BWOAdc\%3d\&tabid=261\&language=en-US

xxv. Mkwizu, K.H.M. (2017d). Proceedings of the International Conference on Tourism, Ethics and Global Citizenship: Connecting the Dots '17: Tourism and Global Citizenship: A perspective of Domestic Tourists visitation profile and social media in Udzungwa National Park in Tanzania. Apeldoorn, Netherlands. Retrieved from http://saxion.nl/wps/wcm/connect/ae736801-f0f0-484e-81f8-

935287550c72/Proceedings+booklet.pdf?MOD=AJPERES\&CACHEID=ae736801-f0f0-484e-81f8-935287550c72

xxvi. Mungai, G. (2011). Tourism marketing Masai Mara National Reserve.(Bachelor thesis). Retrieved from https://www.theseus.fi/bitstream/handle/10024/33139/Mungai_George.pdf?sequence=1

xxvii. Muratha, C. (2013). Methods used by Kenya Tourist Board in marketing adventure tourism in Mount Kenya region. Retrieved from http://publications.theseus.fi/bitstream/handle/10024/63761/MurathaCharles.pdf

xxviii. Mwasha, S., Wilbard, J., \& Jani, D. (2016). Proceedings of the 16th International Conference on African Entrepreneurship and Small Business (ICAESB) '16: Determinants of Tourist Satisfaction in Tanzania Hotels. Dar es Salaam, Tanzania.

xxix. Ngoka, P. (2013). Proceedings of the $8^{\text {th }}$ ATLAS Africa Conference on African Tourism in Global Society: Central of Peripheral?: Tourist visitation of Yankari and Cross River national parks by local and foreign statusesimplications for development of international tourism in Nigeria. Kigali, Rwanda.

xxx. Nguni, W. (2014). Upgrading in local linkages: Examining fresh fruits and vegetables value chain from stakeholders to tourists hotels in Zanzibar. Business Management Review, 17, 35-54.

xxxi. Owusu, A. (2013). Alleviating rural poverty in Ghana through marketing of tourism sites and protected areas. European Journal of Business and Management, 5(1), 6-17.

xxxii. Philemon, J.R.M. (2011). Tourism motivation among University of Dar es Salaam students to visit national parks and game reserves. The Journal of the College of Humanities and Social Sciences Makerere University, 11(2), 8189.

xxxiii. Safari, J., Gowele, V., \& Lwelamira, J. (2015). Involvement in tourism activities and perceived benefits in communities around Udzungwa National park in Tanzania. American Journal of Environment Protection, 4(3), 120-126. 
xxxiv. Sing'ambi, E., \& Lwoga, N.B. (2017). Proceedings of the $10^{\text {th }}$ ATLAS Africa Conference on Africa's Tourism and Travel Competitiveness: Opportunities and Challenges'17: Heritage attachment and domestic tourist's decision to visit Bagamoyo Historic Town, Tanzania. Eldoret, Kenya. Retrieved from http://www.atlaseuro.org/LinkClick.aspx?fileticket=B431-BWOAdc\%3d\&tabid=261\&language=en-US

xxxv. Spencer, D.M. (2013). Effectiveness of intra-destination television advertising of tourist attractions and facilities. Journal of Destination Marketing \& Management, 2(3), 155-164.

xxxvi. Tanzania National Parks. (2015). Retrieved from http://www.tanzaniaparks.com

xxxvii. Tanzania Tourist Board. (2014). Retrieved from http://www.tanzaniatouristboard.com/about-us/ttb-profile xxxviii. Tehrani, A.G., Tehrani, A.G., \& Moghadam, B.H. (2014). Identifying factors affecting creating positive in audiences' attitude towards television advertising from Aborz Azad University student's point of view. Kuwait Chapter of Arabian Journal of Business \& Management Review, 3(6), 54-67.

xxxix. $\quad$ UNWTO. (2017). Retrieved from https://www.unwto.org 